\title{
HISTOMORPHORMETRIC STUDIES ON LACTATIONAL LEAD INTOXICATION IN TESTES OF SPRAGUE DAWLEY RATS
}

\author{
Olajide B N ${ }^{1}$, Odukoya $S$ A $^{2}$, Komolafe $O$ A $^{2}$, Saka $O \mathrm{~S}^{2}$, Odukoya AO ${ }^{3}$
}

${ }^{1}$ Department of Anatomy, Faculty of Basic Medical Sciences, College of Health Sciences, Bowen University, Iwo Osun State ${ }^{2}$ Department of Anatomy and Cell Biology, Faculty of Basic Medical Sciences, Obafemi Awolowo University (OAU), 3Obafemi Awolowo Teaching Hospital (OAUTH), Ile Ife, Osun-State, Nigeria,

*Correspondence to Samson O Ayodeji, Odukoya. Correspondence address: Department of Anatomy and Cell Biology, OAU. Email address: goshevnigeria@yahoo.com; Tel: +2348036153842; +2348076959940

\section{ABSTRACT}

Childhood lead poisoning has been established to cause a lot of health challenges, of which reproductive health perturbation is not least. This research work was designed to investigate the impact of lactational lead exposure on the developing testes in Sprague-Dawley rat pups. 12 female rats were used in the experiment and 23 offspring for the analysis of lactational lead intoxication. The offspring were divided into four groups. Groups B, C and D were administered $10 \mathrm{mg} / \mathrm{dL}, 30 \mathrm{mg} / \mathrm{dL}$ and $70 \mathrm{mg} / \mathrm{dL}$ of lead acetate respectively, via drinking water for 21 days while group A was control. The animal was firstly sedated using a chloroform-damped cotton wool in a vacuum (air-tight chamber). The sedated animal was weighed on a weighing balance and figure recorded. The animal was then perfused to clear blood from the organs before the organs were harvested, the testes of the pups exposed via lactation were observed via histological methods. Statistical analysis showed the total body weight and left testicular weight appeared to be significantly $(p<0.05)$ lower in groups $B, C$ and $D$ when compared to the control group. Right testicular weight, tubular diameter, tubular radius and luminal area were significantly $(p<$ 0.05) higher in groups B, C and D when compared to the control. Testicular distortion was observed during histological findings. Care must be taken by a lactating mother to avoid being exposed to lead during gestation and lactation.

Keywords: Histomorphormetry; Lactation; Testes; Lead-intoxication

\section{INTRODUCTION}

In the male reproductive system, lead poisoning has been known to cause low sperm count and abnormal sperm frequency. In the female reproductive system, lead poisoning is known to cause fertility problems. However, research works are ongoing on how it affects the anatomy and function of the male reproductive system (Qureshi \& Sharma, 2012).The toxicity of lead, on adult female reproduction results in decreased fertility, less ability to sustain pregnancy, and low pregnancy outcomes (Qureshi \& Sharma, 2012).During gestation, lead has the ability to easily cross from the mother's bloodstream to the fetus via the placenta in an unknown mechanism (Brochin et al., 2008). High levels of lead exposure, usually associated with acute exposure, can result in stillbirth or miscarriage (Qureshi \& Sharma, 2012). Lower blood levels, resulting from chronic-low-level exposure or mobilization of bone Lead during pregnancy, are associated with low birth weight and pre-term delivery. Exposure to lead in the workplace or home environment has been implicated as a cause of decreased fertility in women reported. In a study, as part of efforts to determine effects of lead in primates, female 
rhesus monkeys were exposed to lead acetate in drinking water or provided water with no added lead for 33 monkeys. Lead was administered at levels between 2 and $8 \mathrm{mg} / \mathrm{kg} /$ day, with doses adjusted to keep blood lead values near a target of 70 micrograms/dL (Qureshi \& Sharma, 2012). No significant differences were detected between control and experimental animals in body weights, hematocrit, or general health (Qureshi \& Sharma, 2012).Female monkeys whoreceived lead during experiment exhibited longer and more variable menstrual cycles (Qureshi \& Sharma, 2012).

In this study, circulating amounts progesterone (P4) was also determined to evaluate lacteal function. There were no significant differences between groups in mean percent of anovulatory cycles. Therefore, although chronic treatment with the levels of lead used in this study did not prevent ovulation, luteal function was suppressed (Qureshi \& Sharma, 2012).

\section{MATERIALS AND METHODS}

200mg, 600mg and $1400 \mathrm{mg}$ of Lead acetate powder were weighed in a metler Toledo sensitive weighing balance and prepared in $2000 \mathrm{ml}$ of water respectively to obtain $10 \mathrm{mg} / \mathrm{dL}$, $30 \mathrm{mg} / \mathrm{dL}$ and $70 \mathrm{mg} / \mathrm{dL}$ of Lead acetate. These solutions were administered through water dams ad libitum.

A total of 8 male and 8 female Sprague dawley rats having unlimited access to standard rat feed and distilled water were kept under standard laboratory condition at a constant light/dark cycle for them to acclimatize. After acclimatization to the laboratory conditions for 1 week, Sprague Dawley rats (over 100 days old) were made to mate at a proportion of 1 female to 1 male.

After child birth, mothers and their pups were randomly divided into 4 equal groups: 1 control group and 3 treatment groups that received $10 \mathrm{mg} / \mathrm{dL}, 30 \mathrm{mg} / \mathrm{dL}$, and $70 \mathrm{mg} / \mathrm{dL}$ of lead acetate in drinking water from day 1 to day 21 of the lactational period. Then at Postnatal day 22, the pups from each mother were selected, weighed and sedated with chloroform. The animals were then sacrificed. The testes were removed, weighed and fixed by immersion in Bouin's fluid (dispensed in correctly labeled specimen bottles) until taken to the tissue processing laboratory for further processing.

PAS staining was also carried out on all the experimental groups to demonstrate the presence of glycogen on the myocardium of left ventricle. Sections were deparaffinized and hydrated to water. The sections were then oxidized in $0.5 \%$ periodic acid solution for 5 minutes after which they were rinsed in distilled water. After the sections were placed in Schiff reagent for 15 minutes (Sections became light pink color during this step), they were washed in luke warm tap water for 5 minutes (Immediately sections turned dark pink color). They were counterstained in Mayer's hematoxylin for 1 minute, washed intap water for 5 min and then dehydrated and cover slipped using asynthetic mounting medium.

Masson's trichrome staining was also carried out to demonstrate collagen fibers. Slides were deparaffinized and hydrated in distilled water, left to stand for 10 minutes to cool and washed in running water until sections are clear. Rinse in distilled water, stained in Weigert's iron hematoxylin for 10 minutes. Blued in running tap water for 5 minutes, rinse in distilled water also stained in Biebrich scarlet-acid fuschin solution for15 minutes. The slides were differentiated in Phosphotungstic or phosphomolybdic acidsolution for 10 minutes, counterstained in light green solution for 1 minute, save solution and rinse in distilled water. The slides were differentiated in $1 \%$ phosphotungstic acid solution for 15 minutes, dehydrated and cleared through 95\% ethyl alcohol, absolute ethyl alcohol, xylene, 2 changes each, 2 minutes each and Mounted with DPX (Prophet et al., 1992).

Stained sections were viewed under a Leica DM750 microscope (Leica Microsystems, 
Heerbrugg, Switzerland) with digital camera attached (Leica ICC50) and digital photomicrographs were taken at various magnifications. Some data sections were imported onto the Image] version 1.48 ( NIH,
Bethesda, MD, USA) software for elastic cell quantification. One-way ANOVA was used to analyze data, followed by Tukey test for multiple comparisons. Statistically significant difference was set at $\mathrm{p}<0.05$.

\section{RESULTS}

Statistical analysis of the results revealed that in Sprague-Dawley rats, the total body weight appeared to be significantly $(p<0.05)$ higher in groups A (35.50 $\pm 0.50 \mathrm{~g})$ when compared with groups B (22.50 $\pm 0.50 \mathrm{~g}), C(19.50 \pm 0.50 \mathrm{~g})$ and D $(16.50 \pm 0.50 \mathrm{~g})$. Also, the analysis of the weight of the left testis showed a significant $(p<0.05)$ increase in groups $A(86.50 \pm 0.50 \mathrm{mg})$ when compared with B $(83.50 \pm 8.00 \mathrm{~g}) \quad \mathrm{C}$ $(79.50 \pm 1.50 \mathrm{~g})$ and $\mathrm{D}(58.00 \pm 4.00 \mathrm{~g})$. The weight of the right testis appeared to be significantly $(p<0.05)$ higher in control
(88.00 $44.00 \mathrm{mg})$ when compared with other groups (Table 1). Number of seminiferous tubules and germ cell were higher in control group than other groups (Figures 1\&2). Tubular diameter, tubular radius and luminal diameter were significantly $(p<0.05)$ lower in control group when compared with groups $C$ and $D$ (Figures $3 \& 4$ ). Also, there were significantly ( $p$ $<0.05$ ) lower in the control group of tubular and luminal areas when compared with groups $C$ and D (Figures 4 \& 6).

TABLE 1: Showing the mean values for the total body weight and testicular weight across the groups Values are expressed as mean \pm sem, $A=$ control $B=10 \mathrm{mg} / \mathrm{dL} \quad C=30 \mathrm{mg} / \mathrm{dL} \quad D=70 \mathrm{mg} / \mathrm{dL}, T B W=T$ Total Body Weight, LTW=Left testicular weight, RTW=Right Testicular Weigh $p<0.05$

\begin{tabular}{|l|l|l|l|}
\hline Group & TBW $(\mathrm{mg})$ & LTW $(\mathrm{mg})$ & RTW (mg) \\
\hline A & $35.50 \pm 0.50$ & $86.50 \pm 0.50$ & $88.00 \pm 4.0$ \\
\hline B & $22.50 \pm 0.50$ & $83.50 \pm 8.00$ & $86.50 \pm 0.50$ \\
\hline C & $19.50 \pm 0.50$ & $79.50 \pm 1.50$ & $83.00 \pm 8.00$ \\
\hline D & $16.50 \pm 0.50$ & $58.00 \pm 4.00$ & $79.50 \pm 2.12$ \\
\hline
\end{tabular}

\section{Number of seminiferous tubules}

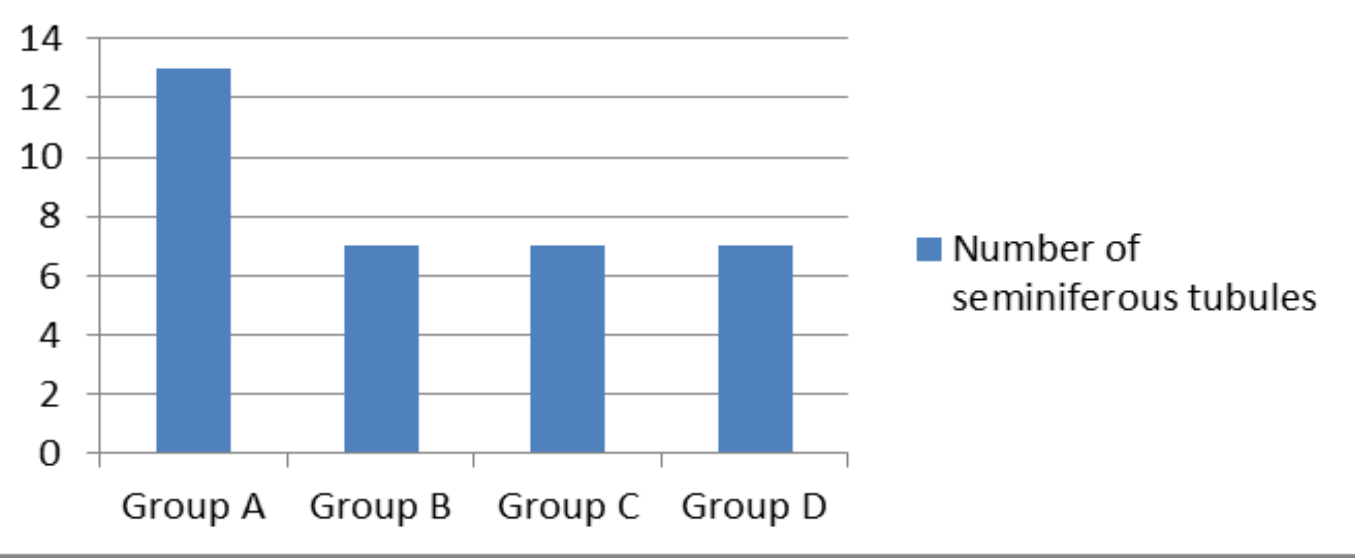

Figure 1: Bar chart showing the number of seminiferous tubules (st) across the groups of lactational lead intoxication in testes of sprague dawley rats. Values are expressed as mean \pm sem, $A=$ control $\mathrm{B}=10 \mathrm{mg} / \mathrm{dL}$ $\mathrm{C}=30 \mathrm{mg} / \mathrm{dL}$ $D=70 \mathrm{mg} / \mathrm{dL}, \mathrm{p}<0.05$ 


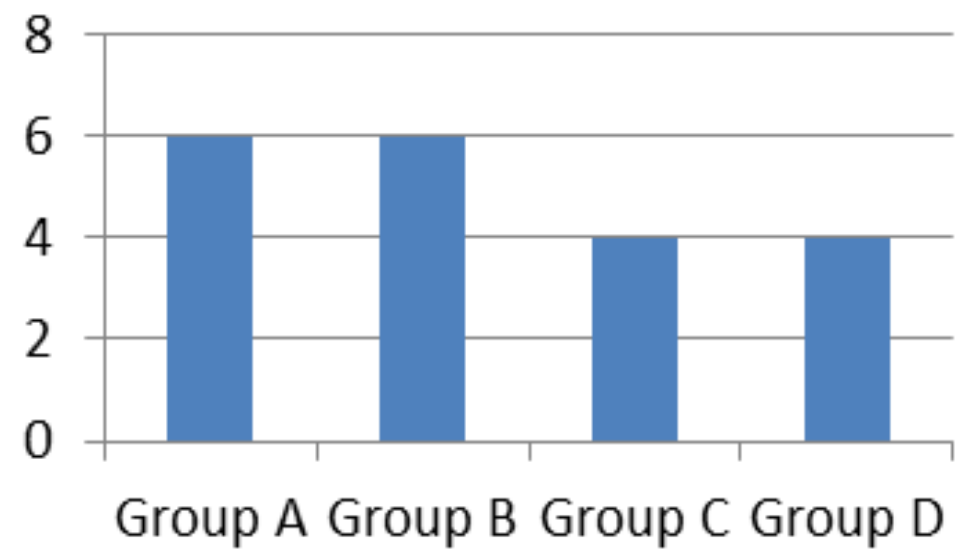

Number of germ cells

Figure 2: Bar chart showing germ cell count across the groups of lactational lead intoxication in testes of sprague dawley rats. Values are expressed as mean \pm sem, $A=$ control $B=10 \mathrm{mg} / \mathrm{dL} \quad C=30 \mathrm{mg} / \mathrm{dL} \quad \mathrm{D}=70 \mathrm{mg} \mathrm{p}<0.05$

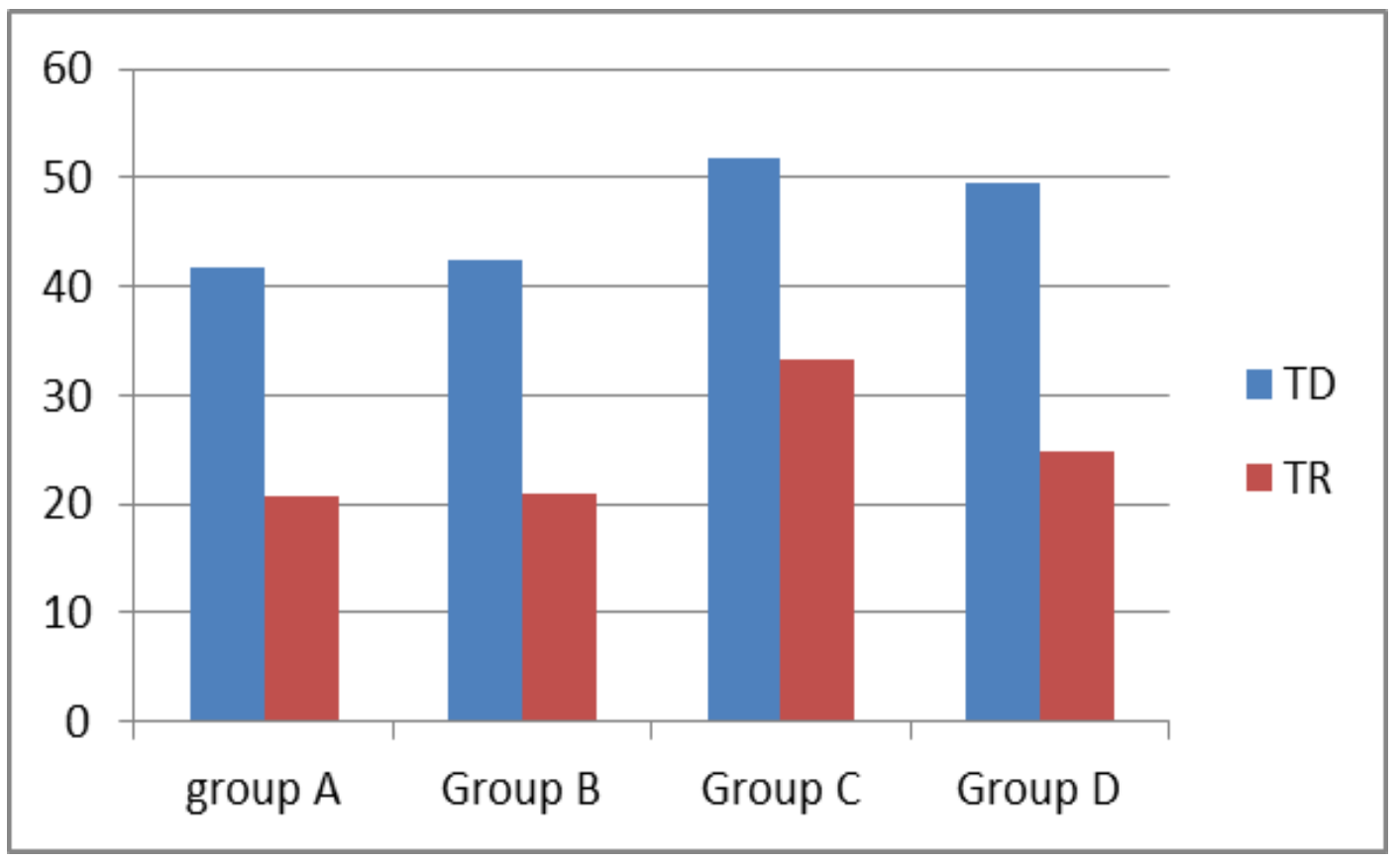

Figure 3: Bar chart showing the tubular diameter (TD) and tubular radius (TR) across the groups of lactational lead intoxication in testes of sprague dawley rats. Values are expressed as mean $\pm \mathrm{sem}, A=$ control $B=10 \mathrm{mg} / \mathrm{dL} \quad C=30 \mathrm{mg} / \mathrm{dL} \quad D=70 \mathrm{mg} \mathrm{p}<$ 0.05 


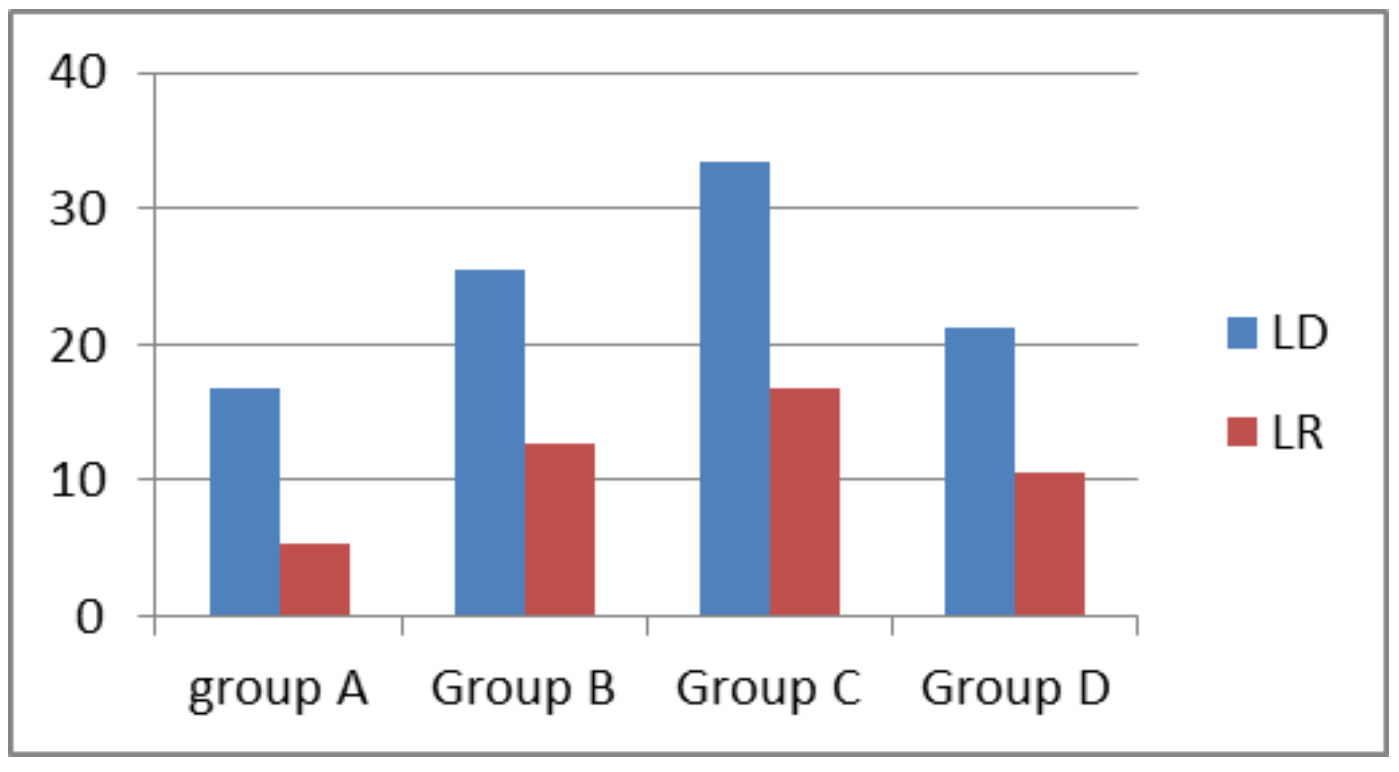

Figure 4: Bar chart showing the luminal diameter (LD) and luminal radius (LR) across the groups of lactational lead intoxication in testes of sprague dawley rats. Values are expressed as mean \pm sem, $A=$ control $B=10 \mathrm{mg} / \mathrm{dL} \quad C=30 \mathrm{mg} / \mathrm{dL} \quad D=70 \mathrm{mg} p<$ 0.05

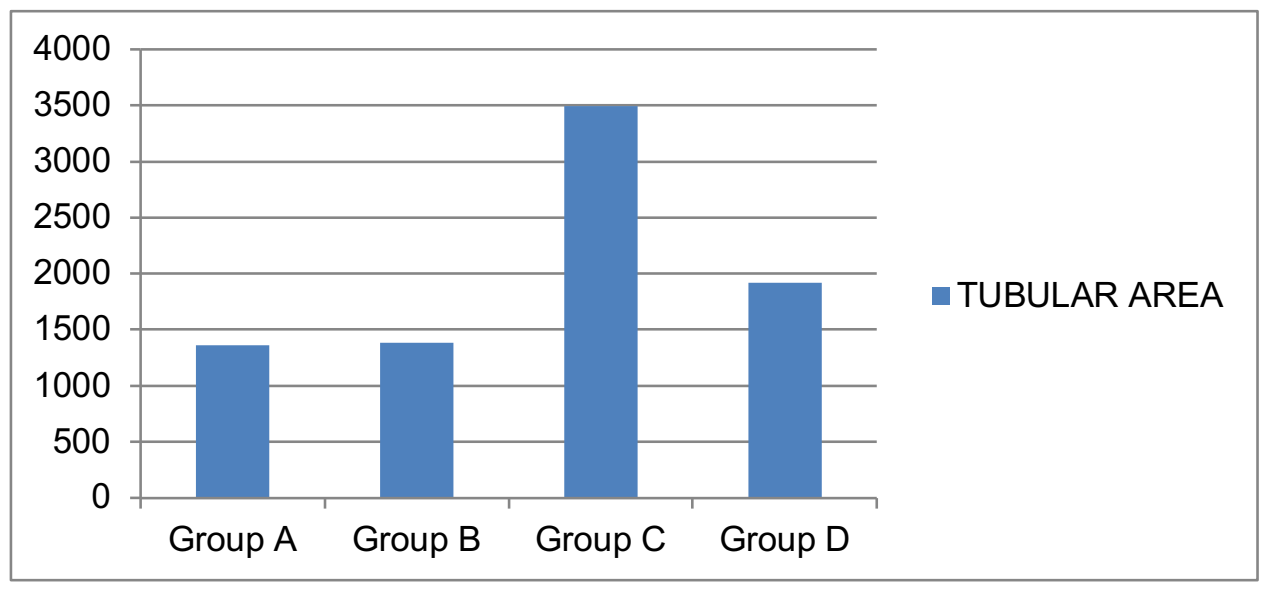

Figure 5: Bar chart showing the tubular area (TA) across the groups of lactational lead intoxication in testes of sprague dawley rats. Values are expressed as mean \pm sem, $A=$ control $B=10 \mathrm{mg} / \mathrm{dL} \quad C=30 \mathrm{mg} / \mathrm{dL} \quad D=70 \mathrm{mg} p<0.05$

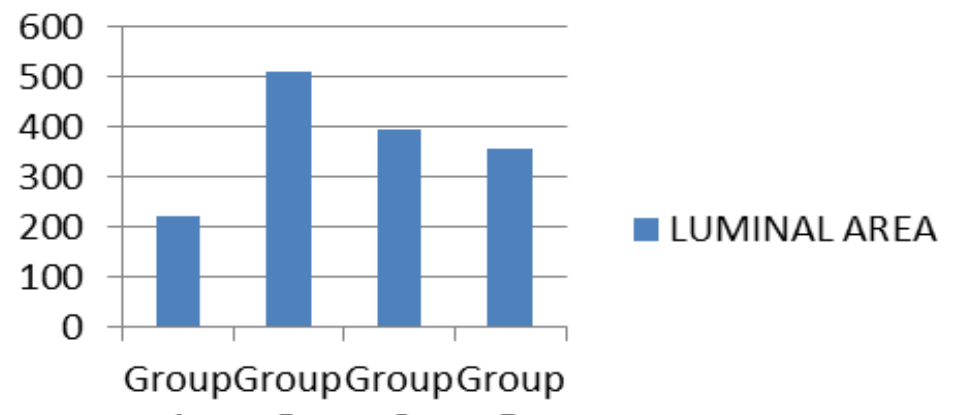
A
C
D

Figure 6: Bar chart showing the luminal area (LA) across the groups of lactational lead intoxication in testes of sprague dawley rats. Values are expressed as mean \pm sem, $A=$ control $B=10 \mathrm{mg} / \mathrm{dL} \quad \mathrm{C}=30 \mathrm{mg} / \mathrm{dL}$ $\mathrm{D}=70 \mathrm{mg} \mathrm{p}<0.05$ 


\section{Histological findings}

The histological features seen with the control group are; basement membrane, seminiferous tubules, leydig cells, Spermatogonia and interstitial tissue in treated group D degenerated cells were seen which indicate atrophy (Figure 7). There was decreased in the number of seminiferous tubules in groups B, C and D suggests atrophy of the testis. The dose-related depletion of collagen fibers indicate a gradual loss of structural integrity of the seminiferous tubules as well as the testis in general. Vacuolation was seen in the group C $(30 \mathrm{mg} / \mathrm{dL})$ group both with the PAS and Masson trichrome stain (Figures 8 and 9)

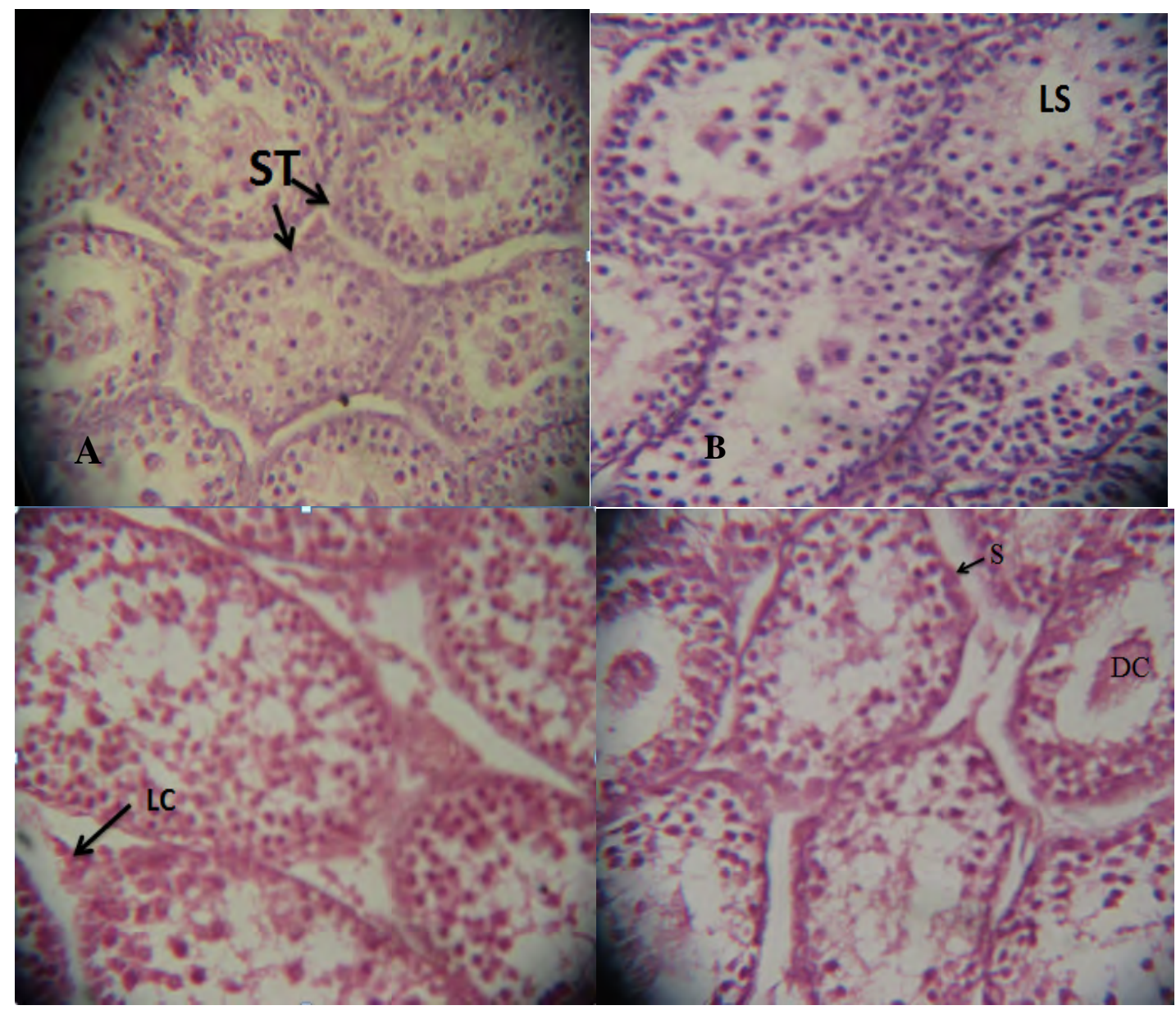

Figure 7: SHOWING TRANSVERSE SECTION OF THE TESTIS. GPNTROL (A), 10MG/DL (B), 30MG/DL (C), 70MG/DL (D), STSemiififerous tubules, LS-Lumen of Seminiferous tubule S- Seminiferous tubule, DC- Debris of degenerated cells. H \& E X400 

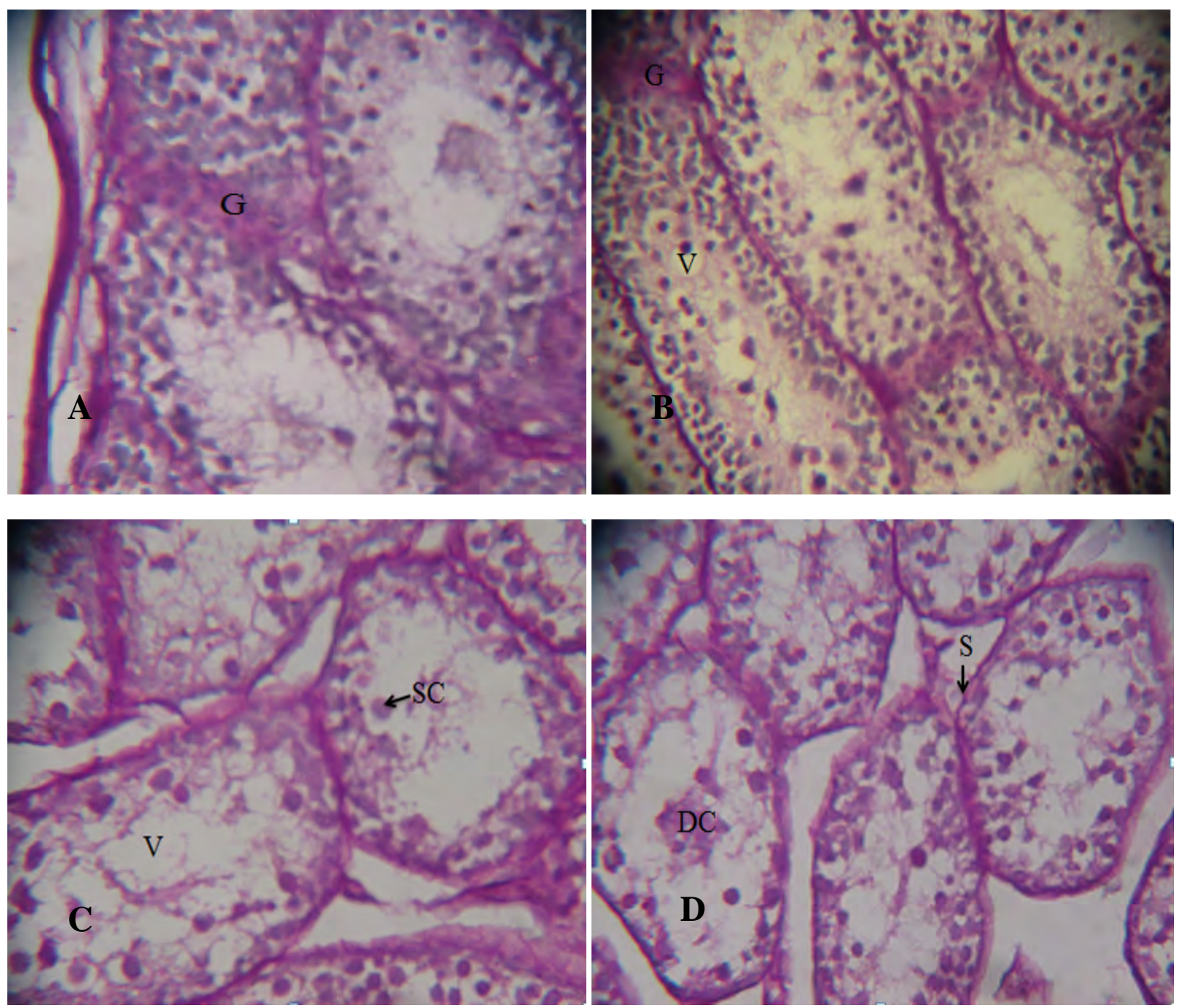

Figure 8: SHOWING TRANSVERSE SECTION OF TESTIS; CONTROL (A), 10MG/DL (B), 30MG/DL (C), 70MG/DL (D), G-purple stain indicating normal glycogen deposition, SC-Relatively spared sertoli cell, V-vacuolation, S-Seminiferous tubule, DC-Debris of degenerated cells. PAS X400 

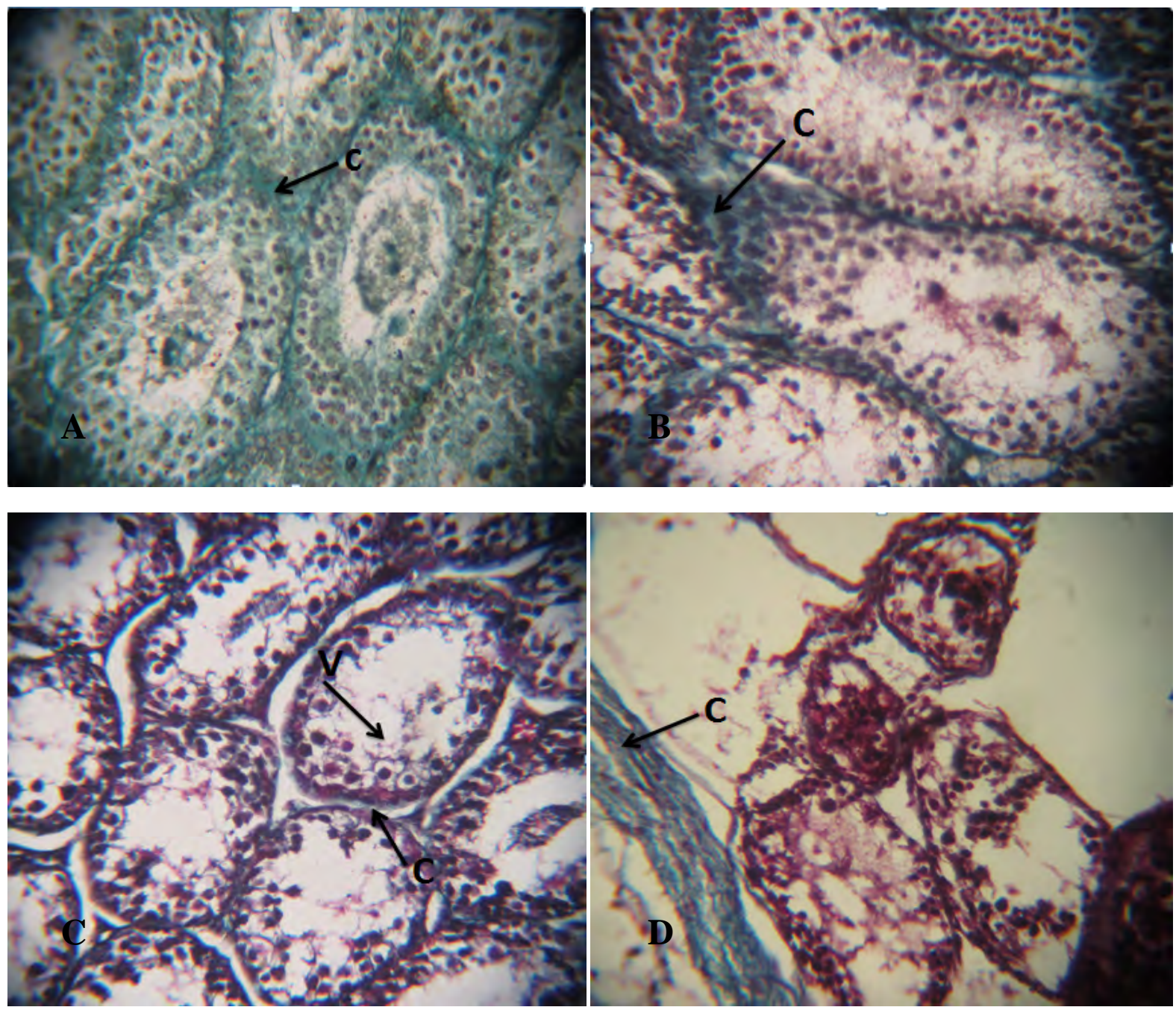

Figure 9: SHOWING TRANSVERSE SECTION OF THE TESTIS; ; CONTROL (A), 10MG/DL (B), 30MG/DL (C), 70MG/DL (D), CCollagen fibers (well distributed in control group and sparsely distributed in the $10 \mathrm{mg} / \mathrm{dL}$ group), (poorly distributed in the $30 \mathrm{mg} / \mathrm{dL}$ group and absent in the $70 \mathrm{mg} / \mathrm{dL}$ group except at the tunica albuginea TA) V-Vacuolation. MT X400

\section{DISCUSSION}

The seminiferous tubules were normal, the Spermatogonia cells were visible and no spermatid or matured spermatozoa was seen as they have not attained sexual maturity in control group. This had earily reported that the maturation of germ cells; from Spermatogonia and early primary spermatocytes, pachytene primary spermatocytes, early to partially developed spermatids, and finally older spermatids occur at about 40 days after birth (Christensen, 2009). In the present study lead induced histhopathological alterations in the various components in developing testis was studied. Daily doses of lead acetate caused significant decrease in the average body weight and significant modifications in the histology of the sprague dawley rats testis. Banu, et al., (2007) reported that lead acetate given in high dose cause dose-dependent significant decrease in body weight of both animals.

The present study, in group C and group D of figure 7 , the lumen of seminiferous tubules was filled with debris of degenerated cells. Spermatogonia were also seen with some degenerated cells which are components of the degenerated cells testis. Besides, Lead altered 
the regular shape of seminiferous tubules and their arrangements. It reduced the germ cells and spermatogonia and disarranged their distribution in seminiferous tubules. In treated group the large gaps were detected between tubules than in control. The histopathological results revealed degeneration of germinal epithelium with sloughing of germ cells had been reported (Yasser and Mahmoud, 2010). Marked decrease in the number of seminiferous tubules in all the treatment groups suggests a marked atrophy of the testis. It had been reported that atrophication of seminiferous tubules and the number of Leydig cells appeared to be lower in lead treated group (Shan, et al., 2009).

The dose-related depletion of collagen fibers in figures 9, indicate a gradual loss of structural integrity of the seminiferous tubules as well as the testis in general. However, the presence of collagen fibers in the tunica albuginea of the $70 \mathrm{mg} / \mathrm{dL}$ group suggests that despite the doserelated depletion, the tunica albuginea still maintains its structural integrity.

The sharp decrease in germ cell count of the group C and group D of figure 2 supports the report by Thomas \& Brogan (1983) and Lancranjan et al., (1975) that Lead acts as a spermicidal agent.

Vacuolation was seen in the group C $(30 \mathrm{mg} / \mathrm{dL})$ group both with the PAS and Masson trichrome stain. All groups showed similar distribution of glycogenon Periodic Acid Schiff (PAS). This suggests that Lactational exposure to Lead has no effect on the testicular glycogen.

Sharma et al., (2012) reported some hematopathological changes in surviving neonates following oral exposure to 8,12 , and $32 \mathrm{mg} / \mathrm{kg}$ of Lead. This report is in line with the blood stain seen in $10 \mathrm{mg} / \mathrm{dL}$ and $30 \mathrm{mg} / \mathrm{dL}$ following lactational exposure suggesting sparse and collapsed blood vessels which was also reported in the work of Ahmad et al., (2003) on the effect of the Lead on the testis of albino rats administered via drinking water.

An experiment of the effect of Lead on the testis of Quail (Cortunix cortunix) also indicated some vascular and interstitial lesions (Almansour, 2009). These reports have helped to establish the damaging effect of Lead on testicular vasculature. Although the seminiferous tubules are enlarged, the reduction in their number coincides with collagen fiber depletion in and around it; except at the tunica albuginea, which still retains their collagen fibers, suggesting testicular atrophy.

In conclusion, testicular atrophy and other histological anomalies observed in this research work is just one of the reproductive toxicological outcomes of Lead intoxication, and as such, care must be taken by a lactating mother to avoid being exposed to lead during gestation and lactation thereby preventing the offspring from the risk of lactational exposure to Lead.

\section{REFERENCES}

1. Ahmad I, Muhammad S, Khalid FY. 2003. Study of the Effect of Lead Poisoning on the Testes in Rats. Pakistan J.Med, Res. Retrieved from www.Pmrc.org.pk on 28/6/2014.

2. Almansour, M.I. 2009. Histological Alteration Induced by Lead in the Testes of the Quail Corturnix cortunix. Research Journal of Environment Toxicology, Vol 3 Issue 1, p24.Retrieved from www.researchgate.com on 27/6/2014.

3. Banu, R., Sharma, R., Qureshi, N. 2007: Amelioration of Lead-induced Alterations in Body Weight and Blood Cell Counts by Antioxidant Vitamins. Journal of Herbal Medicine and Toxicology., 1: 59-66.

4. Brochin, R., Leone, S., Phillips,D. , Shepard,N., Diane Zisa, D., Angerio, A. 2008. The Cellular Effect of Lead Poisoning and Its Clinical Picture. The Georgetown Undergraduate Journal of Health Sciences 5 (2). Retrieved from www.blogs.commons.georgetown.edu on 24/4/2014.

5. Christensen, A.K. 2009. Photographs of Rat Testicular Development. Retrieved from www.personal.umich.edu on 15/5/2014. 
6. Drum, K. 2013. How did lead get into our gasoline:retrieved from www.Motherjones.com on $10 / 4 / 2014$

7. Fredel, J. 2009. Lead Poisoning. Delaware Health and Social Services.Retrieved from www.dhss.delaware.gov on 12/4/2014.

8. Friend, M. 2009. Field Manual of Wild Diseases: retrieved from www.nwhc.usgs.gov on 10/4/2014

9. Goodenough, J., McGuire, B., Wallace, R.A. 2007. Biology of Human, $2^{\text {nd }}$ ed. Pearson. pp. 204.

10. Lancranjan, I., Popescu H.I., Garanescu, O., Klepsch, I. Serbanescn, M. 1975. Reproductive Ability of Workman Occupationally Exposed to Lead. Arch Environ Hlh,30: 396-341. Retrieved from www.Pmrc.org.pk on 28/6/2014.

11. Natural Safety Council. 2009.Lead poisoning: retrieved from www.nsc.org on 10/4/2014

12. Needleman, H.L. 1999. History of Lead poisoning in the world: retrieved from www.biologicaldiversity.org on 10/4/2014

13. Prophet, E.B, Mills, B., Arrington, J.B, Sobin, L.H. 1992. Laboratory methods in Histotechnology

14. Qureshi, N and Sharma, R. 2012. Lead Toxicity and Infertility in Female Swiss Mice. Journal of Chemical, Biological, and Physical Sciences; retrieved from www.jcbsc.com on 12/4/2014.

15. Shan, G., Tang, T. and Zhang, X. 2009. The Protective Effect of Ascorbic Acid and Thiamine Supplementation against Damage Caused by Lead in the Testes of Mice. J. Huazhong. Univ. Sci. Technol. Med. Sci., 29: 68-72.

16. Sharma, R., Qureshi, N., Mogra, S. and Khushbu, P. 2012. Lead Induced Infertility in Swiss mice and Role of Antioxidants.Universal Journal of Environment Research and Technology. Retrieved from www.ncbi.nlm.nih.com on 28/6/2014.

17. Thomas, J.A and Brogan, W.C. 1983. Some Actions of Lead on the Male Reproductive System. Am J Indus, 4(4): 127-34. Retrieved from www.Pmrc.org.pk on 28/6/2014.

18. El-Sayed, Y.S. and El-Neweshy, M.S., 2010. Impact of lead toxicity on male rat reproduction at "hormonal and histopathological levels". Toxicological and Environ Chemistry, 92(4), pp.765-774. 